\title{
INTERNALISASI NILAI-NILAI KARAKTER DAN KECERDASAN MAJEMUK DALAM PENERAPAN KORPUS LINGUISTIK DAN MISSION WALLS
}

\section{Internalization of Character Values and Multiple Intelligences in Linguistic Corpus and Mission Walls Application}

\author{
Eka Lutfiyatun
}

\author{
Mahasiswa Pascasarjana Universitas Islam Negeri Maulana Malik Ibrahim Malang \\ JI Ir. Soekarno No 1, Dadaprejo, Junrejo, Kota Batu, Jawa Timur, Indonesia \\ ekalutfiyatun@gmail.com
}

\begin{abstract}
ABSTRAK: Pembelajaran bahasa asing di Indonesia menemui berbagai problem seperti perbedaan latar belakang bahasa yang dipelajari dengan bahasa ibu, kesulitan siswa di bidang keterampilan membaca dan analisis gramatika, dan perbedaan karakterikstik kecerdasan majemuk yang dimiliki siswa. Guru dituntut untuk menerapkan berbagai teknik pembelajaran yang dapat menyelesaikan tiga permasalahan tersebut. Tujuan kajian ini adalah mendeskripsikan internalisasi nilai-nilai karakter dan kecerdasan majemuk dalam penggunaan media korpus lingustik dan penerapan teknik permainan Mission Walls. Kajian ini menggunakan metode analisis pustaka, dengan menganalisis beberapa karya ilmiah yang merupakan hasil laporan penelitian penggunaan media korpus linguistik dan penerapan Mission Walls dalam rangka penguatan pendidikan karakter dan kecerdasan majemuk. Hasilnya adalah pendidikan karakter dan pembelajaran berbasis kecerdasan majemuk menjadi penting dan integrasi web korpus dan Mission Walls dapat diterapkan. Keseluruhan Mission Walls mengandung 11 nilai karakter, yakni jujur dan rasa ingin tahu, toleransi, kerja keras, tanggung jawab, kreatif, dan demokratis, menghargai prestasi, komunikatif, dan gemar membaca. Kesimpulannya adalah bahwa sangat mungkin bagi guru untuk menggunakan media berbasis web, menerapkan berbagai teknik pembelajaran inovatif, dan mengintegrasikannya ke dalam proses pembelajaran untuk penguatan pendidikan karakter dan kecerdasan majemuk siswa.
\end{abstract}

Kata Kunci: Korpus linguistik, pembelajaran bahasa asing, mission walls, pendidikan karakter, kecerdasan majemuk.

\begin{abstract}
Foreign language learning in Indonesia encounters various problems, such as different background between the learners' mother tongue and foreign language being learned, learners' dificulties in terms of reading skills as well as grammatical analyzing skills, and diferent characteristics of the learners' multiple intelligences. Teachers are required to apply teaching techniques that can overcome these three problems. The objective of this study is to describe the internalization of character values and multiple intelligencces in the application of linguistic corpus media and Mission Walls
\end{abstract}

Eka Lutfiyatun: Internalisasi Nilai-Nilai Karakter dan Kecerdasan Majemuk dalam Penerapan Korpus 
game. The methods applied in this study is literarry review, i.e. by analyzing some scientific writings which are the reports of researches on linguistic corpus media as well as Mission Walls game application in teaching character values and multiple intelligences. The result shows that the teaching on character values as well as multiple intelligences is important; while the integration of web corpus and Mission Walls is applicable. Mission Walls consists of 10 character values, i.e. honesty, curiosity, tolerance, hard work, responsibility, creativity, democracy, appreciation to achievement, communication, and keen of reading. The conclusion is that it is highly possible for teachers to apply web-based media, apply various innovative teaching techniques, and integrate them into teaching learning process to enhance the students' charachter as well as multiple intelligences.

Keywords: The linguistic corpus, foreign language learning, mission walls, character education, multiple intelligences

\section{PEDAHULUAN}

Seiring dengan kemajuan era globalisasi, penguasaan bahasa asing menjadi penting bagi siswa. Tingginya mobilisasi dan arus informasi global yang dengan sangat mudah didapatkan melalui internet, menjadikan penguasaan bahasa asing sangat diperlukan. Bahasa asing yang menjadi bahasa resmi Perserikatan Bangsa-Bangsa (PBB) yang merupakan wadah bagi negara-negara di dunia adalah bahasa Inggris, Arab, Tionghoa, Perancis, Rusia, dan Spanyol. Hal ini berarti sebagai warga negara, kita juga seyogianya dapat menguasai sedikitnya dua bahasa asing sehingga memudahkan kita dalam memperoleh berbagai informasi yang tentunya akan sangat berharga dalam kehidupan kita.

Pemerintah berusaha untuk mendukung hal tersebut dengan memasifkan pembelajaran bahasa asing di sekolah. Siswa diharapkan dapat lebih memantapkan diri dalam menghadapi era globalisasi. Salah satu bahasa asing yang diajarkan di Indonesia adalah Bahasa Arab. Pelajaran bahasa Arab yang diajarkan di sekolah berfungsi sebagai bahasa agama dan ilmu pengetahuan di samping sebagai alat komunikasi (Makruf, 2009: 97).

Pembelajaran bahasa Arab dapat dikatakan berhasil apabila siswa sudah menguasai empat keterampilan berbahasa secara lisan maupun tulisan. Empat keterampilan tersebut meliputi menyimak (mahaarah al-Istima'), berbicara (mahaarah al-takallum), membaca (mahaarah al-qira'ah), dan menulis (mahaarah al-Kitaabah) (Iskandarwassid, 2011: 226). Namun, dalam proses pembelajaran bahasa Arab, siswa mengalami berbagai problematika khususnya dalam membelajari keterampilan membaca.

Hermawan (2011: 143) mendefinisikan pengertian keterampilan membaca sebagai suatu kemampuan mengenali dan memahami isi sesuatu yang tertulis (lambang-lambang tertulis) dengan melafalkan atau mencernanya di dalam hati. Membaca hakekatnya adalah proses komunikasi antara pembaca dengan penulis melalui teks yang ditulisnya yang di dalamnya secara langsung ada hubungan kognitif antara bahasa lisan dengan bahasa tulis.

Menurut Effendy (2009: 167-168), kemahiran membaca dibagi menjadi dua aspek, yaitu pada aspek kedua inilah problematika paling banyak ditemukan. Siswa dituntut untuk mengetahui dan memahami pola-pola kalimat, bentuk kata dalam bahasa Arab, dan kedudukannya dalam kalimat. Apabila siswa tidak tahu hal-hal tersebut, maka mereka akan gagal dalam melafalkan dan memahami bacaan. Perlu adanya media yang dapat membantu mereka memahami materi dan mencapai tujuan pembelajaran. 
Seiring perkembangan zaman, muncul media pembelajaran bahasa Arab elektronik dalam menganalisis teks yaitu Arabic Corpus. Mahasiswa Arab dan Eropa mulai bekerja sama mengembangkan penelitian di bidang Arabic Corpus sejak beberapa dekade ini dengan terus memperbarui data otentik pendukungnya (Al Sulaiti dan Atwell, 2006: 2).

Salah satu contohnya adalah The Quranic Arabic Corpus sebagai media pembelajaran berbasis internet untuk membantu siswa menganalisis kaidah-kaidah gramatika teks berbahasa arab. Media ini berbasis internet yang memuat seluruh teks al-Quran yang disertai dengan makna, bentuk dan kedudukan setiap kata dalam ayat-ayat alQuran beserta terjemahan setiap kata secara rinci.

Aspek lain yang menjadi perhatian guru adalah bagaimana suasana kelas dapat mendukung dan membantu siswa menerima materi dan dapat mengaplikasikannya dalam kehidupan sehari-hari. Kita semua mengetahui bahwa setiap manusia dilahirkan dengan unik yang berarti bahwa setiap manusia mempunyai perbedaan yang dalam perlakuannya tidak dapat selalu disamakan. Salah satu yang menjadi perhatian dunia pendidikan belakangan ini adalah kecerdasan majemuk yang dimiliki setiap siswa.

Schmidt (2003: 32) berpendapat bahwa kecerdasan merupakan kumpulan kepingan kemampuan yang ada di beragam bagian otak. Menurutnya, semua kepingan ini saling berhubungan, tetapi tidak bekerja secara sendiri-sendiri. Sebagai sorang guru tentunya kita harus mengetahui keunikan, kekurangan, dan kelebihan setiap siswa yang kita belajarkan. Hal terpenting bagi kita adalah menyadari dan mengembangkan semua ragam kecerdasan manusia dan kombinasikombinasinya.

Pada dasarnya, manusia mempunyai delapan macam kecerdasan majemuk. Gardner mengelompokkannya menjadi spasial-visual atau berpikir dalam citra gambar, linguistik-verbal, interpersonal atau berinteraksi dengan orang lain, musikal-ritmik, naturalis atau hubungan dengan alam, kinestik atau gerak fisik, intrapersonal atau mengenali diri sendiri, dan logis matematis (Elmubarok, 2009: 116-117).

Selain pada pencapaian pemahaman materi yang lebih bersifat kognitif, aspek afektif dan psikomotorik juga perlu diperhatikan. Aspek afektif pada diri siswa yang merupakan bekal kuat untuk hidup di masyarakat belum dikembangkan secara optimal. Oleh karena itu, pendidikan karakter dan budaya bangsa perlu dikembangkan di sekolah (Suyitno, 2017: 2).

Pendidikan karakter memiliki esensi dan makna yang sama dengan pendidikan moral dan akhlak yang berpijak pada karakter dasar manusia yang bersumber dari nilai moral universal agama. Dengan kata lain, pendidikan karakter merupakan upaya yang dilaksanakan secara sistematis untuk membantu peserta didik memahami nilai-nilai perilaku manusia yang berhubungan dengan Tuhan YME, diri sendiri, sesama manusia, lingkungan dan kebangsaan.

Pendidikan Indonesia mencanangkan 18 nilai karakter berupa: religius, jujur, toleransi, disiplin, kerja keras, kreatif, mandiri, demokratis, rasa ingin tahu, semangat kebangsaan, cita tanah air, menghargai prestasi, komunikatif, cinta damai, gemar membaca, peduli lingkungan, peduli sosial, dan tanggung jawab (Asmani, 2013: 33-35). Penanaman pendidikan karakter yang terintegrasi dalam kegiatan sekolah cukup berhasil dilaksanakan oleh Madrasah Aliyah Nurul Hikmah Banjarnegara (Kohirin, 2015: 96). Begitu pula pada SMK Pondok Pesantren Darul Amanah Kendal yang cukup berhasil menerapkan pendidikan karakter yang terintegrasi dalam pembelajaran, baik intrakurikuler maupun ekstrakurikuler (Anas, 2015: 60).

Pada prinsipnya, pengembangan karakter dan budaya tidak dimasukkan sebagai pokok bahasan tetapi terintegrasi ke dalam mata pelajaran, pengembangan diri, dan budaya sekolah. Oleh karena itu, guru dan sekolah perlu mengintegrasikan nilai-nilai yang dikembangkan dalam pendidikan karakter dan budaya ke dalam kurikulum, silabus dan Rencana Pelaksanaan Pembelajaran (RPP) yang sudah ada (Hasan, 2010: 11). 
Prinsip pembelajaran yang digunakan dalam pengembangan pendidikan karakter dan budaya adalah mengusahakan agar siswa mengenal dan menerima nilai-nilai karakter dan budaya sebagai milik mereka dan bertanggung jawab atas keputusan yang diambilnya melalui tahapan mengenal pilihan, menilai pilihan, menentukan pendirian, dan selanjutnya menjadikan suatu nilai sesuai dengan keyakinan diri. Dengan prinsip ini, siswa belajar melalui proses berpikir, bersikap, dan berbuat. Ketiga proses ini dimaksudkan untuk mengembangkan kemampuan siswa dalam melakukan kegiatan sosial dan mendorong siswa untuk melihat diri sendiri sebagai makhluk sosial (Aziz, 2011: 38). Selain itu, proses siswa sebagai makhluk sosial tidak terlepas dari multikultural yang sebenarnya; nilai tersebut terintegrasi daam penanaman pendidikan karakter.

Rangkaian kata pendidikan dan multikultural memberikan arti secara terminologis sebagai proses pengembangan seluruh potensi manusia yang menghargai pluralitas dan heterogenitasnya sebagai konsekuensi keragaman budaya, etnis, suku, dan aliran (Ibrahim, 2013: 132). Keunikan budaya yang beragam tersebut memberikan implikasi pola pikir, tingkah laku, dan karakter pribadi masing-masing sebagai sebuah tradisi yang hidup dalam masyarakat dan daerah (Ibrahim, 2013: 134).

Berdasarkan uraian di atas, sangat penting adanya integrasi antara penggunaan media dan penerapan teknik pembelajaran dalam mewujudkan pengembangan pendidikan karakter dan kecerdasan majemuk pada diri siswa. Dalam hal ini, dapat disimpulkan bahwa problematika besar yang dialami siswa ada tiga aspek yaitu kesulitan dalam mencapai tujuan pembelajaran atau materi, penguatan karakter, dan pluralitas kecerdasan yang dimiliki siswa.

$\mathrm{Hal}$ tersebut diperkuat dengan penelitian yang dilakukan oleh David dan Roger Johnson (2014). Dikemukakan bahwa tantangan yang harus dihadapi siswa dalam era global seperti sekarang ini adalah cepatnya perkembangan kebudayaan individual masyarakat di dunia yang dapat menyebabkan perbedaan dan perpecahan, serta dituntutnya hubungan antarmanusia yang tak terbatas dengan saling menghargai perbedaan.

Diperlukan adanya model pembelajaran yang dapat memupuk rasa persatuan di antara siswa. Salah satunya adalah dengan pembelajaran kooperatif sehingga siswa dapat belajar untuk bekerja sama dengan orang lain dan berkompetisi namun tetap senang dan menikmati momen yang ada. Kemampuan kooperatif juga merupakan salah satu kecerdasan majemuk yang bersifat interpersonal.

Penelitian di bidang pembelajaran kooperatif sudah banyak dilakukan. Sebagai contoh adalah penelitian yang dilakukan oleh Fitriah dan Hardiadi (2012) yang menyatakan bahwa berdasarkan analisis posttest dengan uji-t satu pihak didapatkan $\mathrm{t}_{\text {hitung }}$ manual sebesar 7,80 dengan $t_{\text {tabel }}$ sebesar 2,04 dengan taraf signifikansi sebesar 0,05. Dengan demikian dapat dinyatakan bahwa hasil belajar menggunakan metode kooperatif dengan model learning tournament di SMK Negeri 1 Sampang lebih baik, dan respon siswa terhadap strategi ini adalah positif dengan rata-rata $70,38 \%$ dan termasuk kriteria respon sangat baik. Kesimpulan ini juga diperkuat oleh hasil penelitian Widhiastuti (2014) yang menyatakan bahwa pembelajaran dengan metode kooperatif tipe Team Game Tournaments dapat meningkatkan partisipasi dan kompetensi belajar siswa.

Dalam hal materi, siswa dituntut untuk mengetahui dan memahami pola-pola kalimat, bentuk kata dalam bahasa Arab, dan kedudukannya dalam kalimat. Apabila siswa tidak tahu hal-hal tersebut, maka mereka akan gagal dalam melafalkan dan memahami bacaan. Selain problematika dalam hal materi, permasalahan lain juga meliputi latar belakang bahasa yang dipelajari. Siswa yang berwawasan kultural Indonesia mempelajari bahasa Arab yang tentu saja harus menyesuaikan perbedaan kebudayaan antara dua bahasa tersebut.

Permasalahan lain adalah perbedaan latar belakang setiap siswa yang diharuskan untuk saling menyesuaikan diri dengan segala perbedaan sudut pandang, kebiasaan, dan 
tentunya pendapat. Dalam hal inilah pendidikan karakter sangat diperlukan. Salah satu yang diusung dalam pendidikan karakter adalah toleransi atau saling menghargai.

Apabila sikap saling menghargai sudah terlaksana, permasalahan yang berkaitan dengan aspek multikultural dapat dikurangi. Hal ini juga sejalan dengan pernyataan Hardini (2017) yaitu bahwa posisi bahasa Arab sebagai salah satu bahasa internasional juga menjadikan pembelajarannya mengandung nilai-nilai multikultural. Baik materi maupun praktiknya diusahakan untuk mengembangkan sikap toleransi terhadap dua kebudayaan yang berbeda dan di saat bersamaan mencoba untuk menanamkan nilai-nilai cinta tanah air dan semangat kebangsaan yang merupakan beberapa nilai yang terkandung dalam pendidikan karakter. Tujuan kajian ini adalah mendeskripsikan internalisasi nilai-nilai karakter dan kecerdasan majemuk yang terkandung dalam teknik permainan Mission Walls. Para guru dapat mengambil manfaat dari kajian pustaka ini yaitu mengenai alternatif media dan teknik pembelajaran yang dapat diterapkan untuk mencapai tujuan pembelajaran. Meskipun dalam kajian ini yang dibahas adalah penerapan dalam pembelajaran bahasa Arab, namun dapat menjadi bahan referensi bagi para guru yang khususnya mengampu mata pelajaran bahasa, baik itu bahasa Indonesia, bahasa daerah, maupun bahasa asing lainnya.

\section{METODA}

Artikel ini adalah kajian kualitatif yang menghasilkan data deskriptif. Desain kajian yang digunakan adalah kajian teks atau pustaka dengan menelaah konsep internalisasi nilai-nilai karakter dan kecerdasan majemuk dalam permainan Mission Walls.

Data yang digunakan dalam kajian ini adalah berbagai literatur yang merupakan kumpulan laporan hasil penelitian karya tulis ilmiah terdahulu seperti skripsi, disertasi, jurnal, artikel, dan prosiding seminar dengan tema media pembelajaran korpus, teknik pembelajaran mission walls, pendidikan karakter, dan pembelajaran berbasis kecerdasan majemuk. Jurnal-jurnal nasional maupun internasional diperoleh melalui online.

Kajian ini menggunakan teknik dokumentasi dengan mengumpulkan data melalui berbagai peninggalan tertulis, seperti buku-buku tentang pendapat dan teori, artikel, jurnal, dan laporan hasil penelitian. Waktu analisis data ini adalah bulan Setember 2017. Teknik analisis data yang digunakan adalah teknik analisis konten (content analysis) dengan memanfaatkan prosedur untuk menarik kesimpulan yang sahih dari berbagai dokumen dan menemukan karakteristik pesan yang dilakukan secara objektif dan sistematis. Langkah selanjutnya adalah membandingkan antara satu tulisan dengan tulisan yang lainnya namun masih dalam bidang yang sama.

\section{HASIL DAN PEMBAHASAN}

Kajian ini membahas tiga hasil penelitian yang berbeda yang sudah diterbitkan dalam bentuk artikel penelitian maupun prosiding seminar. Ketiganya berkaitan erat dengan korpus linguistik, teknik permainan the mission wall, dan pendidikan karakter, serta pembelajaran berbasis kecerdasan majemuk.

Penelitian yang dilakukan Siti Khotijah (2015) yang berjudul "Keefektifan Penggunaan Media Mission $X$ pada Keterampilan Membaca Bahasa Arab Siswa Kelas VIII di SMP Islam Sudirman 1 Bancak Kabupaten Semarang" menunjukkan peningkatan dari pretest ke posttest. Dari data hasil tes dapat diketahui peningkatan nilai rata-rata kelas kontrol dan kelas eksperimen dengan jumlah 22 siswa setiap kelasnya.

Pada pretest, kelas kontrol mendapat nilai rata-rata 62,61 dan posttest mendapat nilai rata-rata 68,86. Pada pretest, kelas eksperimen mendapat nilai rata-rata 62,21, dan posttest mendapat nilai rata-rata 77,95. Kelas eksperimen lebih baik daripada kelas kontrol. Hal ini membuktikan bahwa media tersebut efektif untuk meningkatkan kemampuan membaca siswa.

Penelitian selanjutnya adalah yang dilakukan oleh Eka Lutfiyatun (2017) dengan 
judul Efektivitas Media Korpus dalam Pembelajaran Bahasa Arab Materi Sifat Mausuf dengan Model Quantum Learning. Penelitian ini menggunakan pendekatan kuantitatif dengan analisis hasil tes. Tes diberikan kepada kelas kontrol dan eksperimen dengan jumlah siswa 20 setiap kelasnya. Pada pretest, kelas kontrol mendapat nilai rata-rata 69,7 dan posttest 70.9. Sedangkan pada pretest, kelas eksperimen mendapat nilai rata-rata 69,05 dan posttest 80,65 dan diperoleh $t_{\text {hitung }} 3,295$ dan $t_{\text {tabel }} 1,725$. Dikarenakan $t_{\text {hitung }}>t_{\text {tabel' }}$, dapat ditarik kesimpulan bahwa media korpus linguistik efektif dalam meningkatkan kemampuan siswa.

Amy Johnson dan Mike Raish (2013) dalam penelitiannya yang berjudul "Making Vocabulary Corporeal: Arabic Learners, Vocabulary Development, \& ArabiCorpus" meneliti tentang penerapan media Korpus bahasa Arab berbasis aplikasi yang memuat tentang analisis teks berbahasa Arab yang bersumber dari artikel surat kabar seluruh wilayah Timur Tengah. Media ini berfungsi untuk membantu siswa dalam mengidentifikasi part of speech setiap kata yang ada di dalam teks. Media ini juga membantu mahasiswa di semester empat dalam menerjemahkan teks bacaan sesuai dengan konteks. Amy Johnson dan Mike Raish (2013) menerapkan media yang berbasis pada aplikasi offline dan teks artikel berita yang sudah terinput sistem.

Berikut adalah contoh tampilan halaman The Quranic Arabic Corpus.

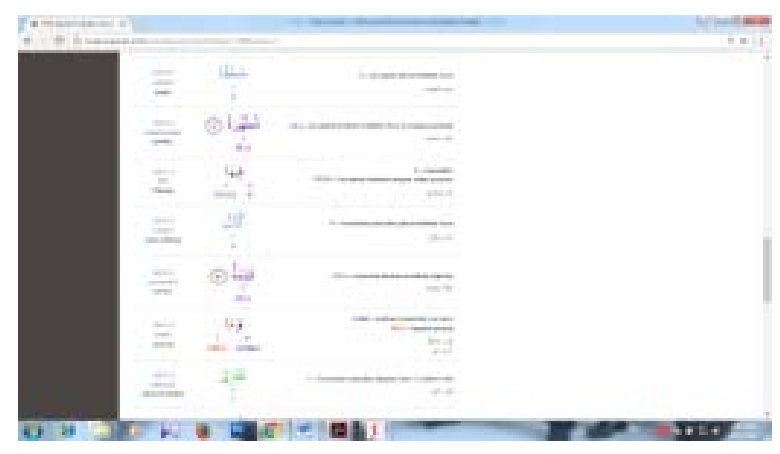

Gambar Tampilan The Quran Arabic Corpus. Sumber: www.corpus.quran.com

Setelah diamati, ketiga penelitian yang dilakukan Siti Khotijah (2015), Eka Lutfiyatun
(2017), dan Amy Johnson dan Mike Raish (2013) tampak memiliki benang merah yang dapat memberikan pengetahuan bagi para praktisi pendidikan. Tema besar dari ketiga penelitian tersebut adalah usaha pengembangan teknologi pendidikan untuk memecahkan masalah dalam pembelajaran bahasa Arab. Siti Khotijah (2015) dan Eka Lutfiyatun (2017) dapat dikatakan berhasil memecahkan masalah yang ada di sekolah masing-masing dengan menerapkan teknik permainan Mission Walls atau Mission X.

Apabila diperhatikan, kedua penelitian tersebut menggunakan konsep model pembelajaran kooperatif tipe Team Game Tournaments (TGT). Pembelajaran kooperatif adalah model pembelajaran yang berfokus pada penggunaan kelompok kecil siswa untuk bekerja sama dalam memaksimalkan kondisi belajar untuk mencapai tujuan belajar (Sugiyanto 2010: 37).

Model TGT ini juga pernah diteliti oleh Eka Lutfiyatun (2015) dalam pembelajaran bahasa Arab dengan media bantu aplikasi game edukasi yang dimainkan secara berkelompok. Hasil penelitian tersebut juga mendukung pernyataan bahwa model TGT dapat meningkatkan partisipasi siswa dalam kegiatan pembelajaran di kelas.

Benang merah antara penelitian Eka Lutfiyatun (2017) dan Amy Johnson dan Mike Raish (2013) adalah pemanfaatan teknologi berbasis komputer untuk membantu siswa memahami materi pelajaran. Penelitian Amy Johnson dan Mike Raish (2013) memberikan ide baru dalam pembelajaran bahasa Arab sebagai bahasa asing khususnya di bidang analisis gramatika dan pemahaman bacaan. Benang merah tersebut diperkuat oleh hasil penelitian Mohamed Abdelhaged Mansour (2013) yang menyatakan bahwa Korpus digunakan sebagai media deskripsi dan analisis. Lebih jauh lagi ia juga menjabarkan fungsi lain korpus dalam pembelajaran dengan memberikan kontribusi di dalam banyak aspek. Pertama, menyediakan datadata linguistik empiris yang dapat diteliti oleh para ahli bahasa dengan lebih objektif. Kedua, membantu para peneliti bahasa terhindar dari generalisasi bahasa padahal latar belakang bahasa jelas berbeda. Ketiga, para peneliti 
sangat dimungkinkan untuk mendapatkan data yang diingikan dari megadata korpus dengan sangat mudah karena terintegrasi dengan komputer dan perangkat lunak yang canggih. Keempat, ahli bahasa juga dapat menguji dan merevisi teori-teori berkenaan dengan korpus yang sudah ada.

Almujalwel (2016) juga menemukan hal yang sama dalam penelitiannya bahwa korpus dapat digunakan dalam eksplorasi pembelajaran bahasa karena akses yang relatif tak terbatas dengan sumber yang mudah diakses. Meskipun dapat menyelesaikan permasalahan, penelitian Siti Khotijah (2015), Eka Lutfiyatun (2017), serta Amy Johnson dan Mike Raish (2013) tentunya mempunyai beberapa aspek kelemahan.

Pertama, kelemahan dalam penelitian Siti Khotijah (2015) yang dilakukan di desa menyebabkan teknologi pendidikan yang dikembangkan hanya pada ranah pembelajaran dan tidak dapat menyentuh ranah pengembangan dan penggunaan teknologi berbasis internet. Namun kelebihannya adalah cara ini dapat dicoba pada daerah-daerah lain yang belum terjamah teknologi tingkat tinggi, baik dalam pembelajaran bahasa maupun non bahasa karena langkah-langkah teknik permainan yang ditawarkan sangat universal dengan tujuan dapat diaplikasikan pada mata pelajaran lain.

Kedua, penelitian Amy Johnson dan Mike Raish (2013) memberikan ide baru dalam pembelajaran bahasa Arab yang terkenal dengan pembelajaran monoton. Hal ini tentu saja dapat diterapkan di berbagai tempat lain, namun sayangnya korpus yang mereka kembangkan masih terbatas pada teks-teks surat kabar yang akan susah dimengerti gaya bahasanya oleh pembelajar pemula.

Ketiga, penelitian Eka Lutfiyatun (2017) mempunyai kelebihan dalam pengembangan teknologi pendidikan dalam dua aspek sekaligus, yaitu pembelajaran dan teknologi berbasis internet karena media korpus yang digunakan berbasis web online. Namun, kelemahannya adalah media ini tidak dapat digunakan di daerah-daerah yang susah terjangkau internet sehingga pemanfaatan media ini sangat terbatas pada sekolah- sekolah di daerah yang tersedia jaringan internetnya.

Selanjutnya apabila dianalisis lebih lanjut, penelitian Siti Khotijah (2015) dan Lutfiyatun (2017) tentang pengembangan teknik permainan Mission Walls mempunyai misi tersembunyi dalam penguatan pendidikan karakter. Konsep teknik permainan The Mission Wall juga menggunakan media berupa kartu-kartu misi. Misi yang dimaksud adalah pertanyaan-pertanyaan seputar materi bahasa Arab. Media The Mission Wall ini mempunyai enam misi di mana setiap misinya itu terdapat beberapa pertanyaan yang harus dijawab siswa. Misi atau pertanyaan tersebut berupa materi yang ada dalam teks bacaan bahasa Arab. Adapun cara menggunakan media mission $X$ ini adalah sebagai berikut (Lutfiyatun, 2017: 7).

1. Siswa dikelompokkan menjadi empat kelompok dimana tiap kelompok itu diberi name tag;

2. Setiap kelompoknya diberi name tag yang terdiri dari empat bentuk yaitu (1) power rangers, (2) Unyil, (3) Shinchan dan (4) Upin ipin;

3. The Mission Wall yang terbuat dari kertas berisi enam kartu misi/pertanyaan yang harus dijawab;

4. Kelompok yang ingin menjawab pertanyaan, terlebih dahulu menunjuk atap dengan tongkat yang masing-masing dipegang ketua kelompok dan setelah dipersilakan guru, kelompok menyerukan tagline:

Powerrangers
Unyil
Shinchan
Upintpin

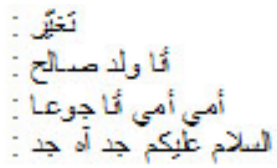

5. Salah satu perwakilan kelompok mengocok dadu. Apabila nomor 3 yang keluar maka kelompok yang paling cepat tunjuk tongkat dan menyebutkan tagline kelompoknya berhak mendapatkan poin yang tertera dalam kartu misi jika jawabannya memang benar, dan begitu seterusnya. 
6. Adapun daftar misi yang harus diselesaikan adalah:

a. Strip Story: Siswa mengurutkan frasa menjadi paragraf.

b. Membaca nyaring secara estafet: salah satu anggota kelompok terpilih membacakan sebuah paragraf. Ketika guru mengatakan "next" maka anggota lain dalam kelompok tersebut meneruskan bacaan dengan pelafalan yang tepat, dan begitu seterusnya.

c. Masing-masing kelompok diberikan 5 pertanyaan berbeda yang jawabannya berkaitan dengan isi bacaan yang sudah diberikan pada kegiatan pemaparan materi (membaca pemahaman).

d. Guru memberikan sebuah kertas kepada salah satu kelompok untuk dibacakan. Kelompok lain menentukan benar/salah terhadap ekspresi atau ungkapan yang dibacakan (memahami makna tersirat bacaan).

e. Guru memberikan sepotong kertas yang berisi kalimat/ungkapan kepada salah satu anggota dari kelompok terpilih. Anggota tersebut berdiri di depan kelas dan memperagakan apa yang tertulis pada kertas tersebut. Anggota lain yang tersisa dari kelompok terpilih mencoba menebak apa maksud dari gerakan tersebut (mengungkapkan kembali pemahaman terhadap kalimat yang dibaca).

f. Siswa melengkapi paragraf rumpang dengan memilih kosakata yang telah disediakan.

Bila diamati setiap langkah dalam permainan tersebut, terlihat integrasi antara pendidikan karakter dan pembelajaran berbasis kecerdasan majemuk. Berikut adalah uraian detail mengenai identifikasi tersebut: (1) Misi A mengandung nilai kerja keras dan kreatif, serta dapat mengasah kecerdasan verbal, spasial, kinestik, dan interpersonal; (2) Misi B mengandung nilai komunikatif dan gemar membaca, serta dapat mengasah kecerdasan verbal dan interpersonal; (3) Misi C mengandung nilai mandiri dan tanggung jawab, serta dapat mengasah kecerdasan logis, verbal, dan intrapersonal; (4) Misi D mengandung nilai rasa ingin tahu dan dapat mengasah kecerdasan logis, naturalis, dan intrapersonal; (5) Misi E mengandung nilai komunikatif dan mengasah kecerdasan verbal, interpersonal, spasial, dan logis; dan (6) Misi F mengandung nilai gemar membaca, kreatif dan tanggung jawab, serta mengasah kecerdasan spasial, verbal, dan logis.

Permainan ini pada dasarnya menerapkan model pembelajaran kooperatif yang menuntut siswa untuk bekerja secara berkelompok untuk mencapai tujuan tertentu. Hal ini sejalan dengan model pembelajaran kooperatif Johnson dan Johnson yang dikutip oleh Abdulkarem dan Al Jadiry dalam jurnalnya (2012: 557) bahwa harus ada lima kriteria pembelajaran kooperatif yaitu: (1) Saling ketergantungan antarpemain, maksudnya adalah siswa belajar bekerjasama untuk mencapai tujuan, saling membantu dan memberikan arahan; (2) Kemampuan individu dalam bertanggungjawab akan sangat terlihat karena ia mempunyai tugas tersendiri untuk mendukung kelompoknya; (3) Adanya interaksi langsung antarkelompok. Selama permainan sangat dimungkinkan bagi setiap kelompok untuk mengevaluasi kinerja mereka dan menentukan keputusan untuk strategi kelompok yang lebih baik; dan (4) Perkembangan kemampuan dalam memberikan umpan balik, mengambil konsekuensi, dan kerjasama benar-benar diasah.

Pendapat di atas juga diperkuat oleh Abdullah (2009: 173) bahwa pembelajaran kooperatif membantu siswa untuk berbagi masalah, tujuan, tugas, dan keberhasilan dengan anggota kelompok yang lain yang dapat diwujudkan, baik melalui eksperimen langsung maupun proyek berbasis masalah sehingga dapat menguatkan kemampuan interpersonal, saling menghargai, empati dan menentukan sudut pandang terhadap suatu masalah yang sesuai.

Saling menghargai adalah kunci dari pendidikan multikultural dan salah satu nilai 
karakter bangsa yang diusung oleh Keputusan Menteri Pendidikan Nasional. Ratna Megawangi merumuskan pendidikan karakter sebagai suatu usaha untuk mendidik anak-anak agar dapat mengambil keputusan dengan bijak dan mengimplementasikannya dalam kehidupan sehari-hari sehingga mereka dapat memberikan kontribusi positif pada lingkungannya (2011: 5).

Lebih jelasnya, pendidikan karakter menurut Kepmendiknas (2010: i-ii) pada satuan pendidikan telah teridentifikasi 18 nilai yang bersumber dari agama, Pancasila, budaya, dan tujuan pendidikan nasional yaitu: (1) religius, (2) jujur, (3) toleransi, (4) disiplin, (5) kerja keras, (6) kreatif, (7) mandiri, (8) demokratis, (9) rasa ingin tahu, (10) semangat kebangsaan, (11) cinta tanah air, (12) menghargai prestasi, (13) bersahabat/ komunikatif, (14) cinta damai, (15) gemar membaca, (16) peduli lingkungan, (17) peduli sosial, dan 18) tanggung jawab.

Apabila diamati lebih jauh lagi, secara keseluruhan permainan Mission Walls mengandung setidaknya 11 nilai karakter tersebut, yakni jujur dan rasa ingin tahu dalam menjawab pertanyaan pada setiap misi, toleransi terhadap perbedaan pendapat, kerja keras, tanggung jawab, kreatif, dan demokratis dalam menjalankan setiap misi, menghargai prestasi, komunikatif, dan gemar membaca. Hal ini membuktikan bahwa pendidikan karakter haruslah terintegrasi dalam proses belajar.

Pendapat tersebut diperkuat oleh penelitian Thompson (2002) yang menyatakan bahwa pendidikan karakter seyogianya terintegrasi dengan kurikulum, bukan merupakan pelajaran terpisah. Tanggung jawab dan saling menghargai sesama atau toleransi adalah dua aspek yang biasanya paling dapat diidentifikasi. Implikasinya dalam pembelajaran berbasis kecerdasan majemuk adalah permainan tersebut berbasis permainan kelompok dan linguistik verbal. Hal ini menunjukkan bahwa dalam proses belajar-mengajar yang menggunakan game akan lebih banyak terjadi interaksi yang semakin menguatkan kecerdasan verbal dan intrapersonal. Ciri-ciri interaksi dalam pembelajaran yang dikemukakan Sardiman (2004: 7) dapat dijelaskan sebagai berikut: (1) interaksi dalam pembelajaran memiliki tujuan, yaitu untuk membantu anak dalam perkembangan tertentu dengan menempatkan anak sebagai pusat perhatian; (2) ada suatu prosedur (jalannya interaksi) yang direncanakan dan didesain untuk mencapai tujuan yang telah ditetapkan; (3) interaksi pembelajaran ditandai dengan satu penggarapan materi yang khusus. Dalam hal ini, materi harus didesain sedemikian rupa sehingga cocok untuk mencapai tujuan; (4) ditandai dengan adanya aktivitas siswa sehingga siswa sebagai sentral dan menjadi syarat mutlak bagi berlangsungnya interaksi belajarmengajar; dan (5) dalam interaksi pembelajaran dibutuhkan disiplin. Disiplin dalam interaksi pembelajaran diartikan sebagai suatu pola perilaku sedemikian rupa menurut ketentuan yang sudah ditaati oleh semua pihak secara sadar.

$\mathrm{Hal}$ tersebut di atas juga diperkuat oleh penelitian Aryani, Sutjito, dan Sudarmi (2014) tentang pembelajaran berbasis kecerdasan majemuk. Berdasarkan hasil analisis data, diperoleh persentase ketercapaian kognitif siswa sebesar $83 \%$. Nilai ini lebih besar daripada standar minimum ketercapaian kognitif yaitu $70 \%$. Sementara itu, aktivitas mandiri (intrapersonal) didapati memiliki persentase tertinggi, yaitu $78,15 \%$ diikuti oleh aktivitas berkelompok siswa yang hanya 54,6\%. Rencana Pelaksanaan Pembelajaran (RPP) dikembangkan dengan pertimbangan dominasi aktivitas mandiri (intrapersonal).

Berbagai penelitian di atas menunjukkan bahwa dalam pembelajaran, sangat memungkinkan bagi guru untuk menggunakan media pendukung berbasis teknologi informasi terutama yang berbasis web, penerapan berbagai teknik pembelajaran yang kreatif dan inovatif serta megintegrasikannya dengan pegembangan pendidikan karakter dan pembelajaran berbasis kecerdasan majemuk.

Pengembangan teknologi pendidikan pun bukan hanya sebatas pada penggunaan media berbasis internet saja, tetapi juga dalam hal pengembangan media non teknologi informasi dan komunikasi asalkan media 
tersebut dapat menyelesaikan permasalahan dalam pembelajaran. Penerapan permainan bahasa pun ternyata dapat menjadi wahana penguat nilai-nilai pendidikan karakter dan pengembangan kecerdasan majemuk siswa.

\section{SIMPULAN DAN SARAN}

Keseluruhan permainan Mission Walls mengandung setidaknya 11 nilai karakter, yakni jujur dan rasa ingin tahu dalam menjawab pertanyaan pada setiap misi, toleransi terhadap perbedaan pendapat, kerja keras, tanggung jawab, kreatif, dan demokratis dalam menjalankan setiap misi, menghargai prestasi, komunikatif, dan gemar membaca. Selain itu, permainan ini juga menunjukkan pengembangan kecerdasan majemuk dalam aspek spasial, interpersonal, intrapersonal, naturalis, verbal, dan logis.

Guru perlu menerapkan berbagai teknik pembelajaran yang dapat menggugah semangat belajar siswa meskipun harus mempelajari materi dengan tingkat kesulitan yang relatif tinggi. Salah satu cara yang dapat dicoba adalah dengan penggunaan media korpus linguistik berbasis web yang bernama The Quranic Arabic Corpus dan juga penerapan teknik pembelajaran mission walls.

Artikel ini menggunakan metode analisis kajian pustaka dengan menganalisis beberapa karya ilmiah hasil penelitian penggunaan media korpus linguistik dan penerapan the mission wall dalam pembelajaran bahasa asing. Tujuannya adalah untuk penguatan pendidikan karakter dan pengembangan pembelajaran berbasis kecerdasan majemuk.

Di era modern seperti sekarang ini, sebagai guru yang baik, harus berusaha untuk mengetahui kebutuhan dan latar belakang siswa yang menjadikan sebuah pendidikan karakter dan multikultural sebagai aspek yang sangat penting. Selain itu, penerapan teknik pembelajaran yang dapat meningkatkan motivasi dan pemahaman siswa juga tidak kalah pentingnya. Oleh karena itu, tidak tertutup kemungkinan sebagai seorang guru untuk senantiasa mengikuti perkembangan zaman yang ada dan menyesuaikan dengan perkembangan dan kebutuhan siswa.

\section{PUSTAKA ACUAN}

\section{Buku}

Asmani, Jamal Ma'mus. 2013. Buku Panduan Internalisasi Pendidikan Karakter di Sekolah. Yogyakarta: DIVA Press.

Dharma, Kesuma., dkk. 2011. Pendidikan Karakter Kajian Teori dan Praktik di Sekolah. Bandung: PT Remaja Rosda Karya.

Effendy, A. F. 2009. Metodologi Pengajaran Bahasa Arab. Malang: Misykat.

Elmubarok, Zaim. 2009. Membumikan Pendidikan Nilai: Mengumpulkan yang Terserak, Menyambung yang Terputus, dan Menyatukan yang Tercerai. Bandung: Alfabeta.

Hermawan, Acep. 2011. Metodologi Pembelajaran Bahasa Arab. Bandung: PT. Remaja Rosdakarya.

Iskandarwassid, \& Sunendar, D. 2011. Strategi Pembelajaran Bahasa. Bandung: PT. Remaja Rosdakarya.

Makruf, Imam. 2009. Strategi Pembelajaran Aktif. Semarang: Need's Press.

Sardiman, A. M. 2004. Interaksi dan Motivasi Belajar Mengajar. Jakarta: Raja Grafindo Persada.

Sugiyanto. 2010. Model-model Pembelajaran Inovatif. Surakarta: Yuma.

\section{Jurnal/Prosiding/Disertasi/Tesis/Skripsi}

Abdulkarem, Raed dan Al Jadiry, Adnan. 2012. The Effect of Using Cooperative Learning on Multiple Intelligences Theory on Physical Concept Acquisition. An article in British Journal of Arts and Social Science Vol 10 No II. ISSN: 2046-9578. London: British Journal Publishing.

Abdullah, Ana Christina. 2009. Multicultural Education in Early Childhood: Issues and Challenges. An article in Journal of International Cooperation in Education Vol 12 No 1. Hiroshima: Hisroshima University.

Al Sulaiti, L., \& Atwell, E. 2006. The Design of a corpus of Contemporary Arabic. University of 
Leeds. An article in Internastional Journal of Linguistics, 1384-6655. Amsterdam: John Benjamins Publising Company.

Anas, Wakhid Anwar. 2015. Penerapan Pendidikan Karakter dalam Proses Pembelajaran di SMK Pondok Pesantren Darul Amanah Kendal. Skripsi. Semarang: Universitas Negeri Semarang.

Fitriah, Raden Ayu. Eko Hariadi. 2012. Pengaruh Metode Pembelajaran Learning Tournament Terhadap Hasil Belajar Siswa di SMK Negeri 1 Sampang. Artikel dalam Jurnal Penelitian Pendidikan. Vol 1. No 1. Surabaya: Universitas Negeri Surabaya.

Ibrahim. 2013. Jurnal Addin: Pendidikan Multkultural. Surakarta: UNU Press.

Johnson, A., \& Raish, M. 2013. Making Vocabulary Corporeal, Arabic Learners, Vocabulary Development, and arabiCorpus. Proceedings of the International Linguistics.

Kohirin, Felik. 2015. Implementasi Nilai-Nilai Pendidikan Karakter di Madrasah Aliyah Nurul Hikmah Banjarnegara. Skripsi. Semarang: Universitas Negeri Semarang.

Lutfiyatun, Eka. 2015. Pengembangan Game Edukasi Berbasis Adobe Flash CS5 untuk Keterampilan Menulis. Skripsi. Universitas Negeri Semarang.

Lutfiyatun, Eka. 2017. Efektifitas Media Corpus Linguistik dalam pembelajaran bahasa Arab. Prosiding Seminar Nasional. Yogyakarta: UNY Press.

Mansour, Mohamed Abdelhageed. 2013. The Absence of Arabic Corpus Linguistics: A Call for Creating an Arabic National Corpus. An article in International Journal of Humanities and Social Science Vol 3 No 12. Egypt: Assiut University.

Schmidt, Laurel. 2003. Jalan Pintas Menjadi 7 Kali Lebih Cerdas. Bandung: Mizan Media Utama. Siti Khotijah 2015. Keefektifan Penggunaan Media Mission X pada Keterampilan Membaca Bahasa Arab Siswa Kelas VIII di SMP Islam Sudirman 1 Bancak Kab. Semarang. Skripsi. Tidak diterbitkan. Semarang: Universitas
Negeri Semarang.

Thompson, William G. 2002. The Effect of Character Education on Student Behavior. Disertasi. Tennesse: East Tennesse State University.

Widhiastuti, Ratieh. 2014. Teams Games Tournament (TGT) sebagai Metode untuk Meningkatkan Keaktifan dan Kemampuan Belajar. Artikel dalam Jurnal Dinamika Pendidikan. Vol IX. No 1, 2014.

\section{Lain-lain}

Almujalwel, Sultan, dan Al Thubaity, Abdulmohsen. 2016. Arabic Corpus Processing Tools for Corpus Linguistics and Language Teaching. Makalah Seminar. Tersedia secara online di https://www.researchgate.net/publication/ 309351881 (Diunduh tanggal 15 September 2017).

Aryani, Dwi Agustin, dkk. 2014. Edusains: Model Pembelajaran Berdasarkan Teori Multiple Intelligence yang Dominan dalam Kelas pada Materi Tekanan. Tersedia secara online di https://media.neliti.com/media/publications/ 58981-ID-model-pembelajaran-berdasarkanteori-mul.pdf (Diunduh tanggal 15 September 2017).

Hardini, Tri Indri. 2017. Presentasi Materi Seminar Nasional: Inovasi Pembelajaran Bahasa Asing Berciri Multikultural. 14 September 2017 di Universitas Negeri Semarang.

Johnson, David dan Johnson, Roger. Anales de Palcologia. 2014. Cooperative Leraning in $21^{\text {st }}$ Century. Tersedia secara online di http:// dx.doi.org/ 10.6018/analesps.30.3.201241 (Diunduh tanggal 15 September 2017).

Suyitno, Imam. 2017. Pengembangan Pendidikan Karakter dan Budaya Bangsa Berwawasan Kearifan Lokal. Sumber: Error! Hyperlink reference not valid. (Diunduh 15 September 2017).

\section{UCAPAN TERIMA KASIH}

Ucapan terima kasih disampaikan kepada Pustekkom Kemdikbud Republik Indonesia,

Eka Lutfiyatun: Internalisasi Nilai-Nilai Karakter dan Kecerdasan Majemuk dalam Penerapan Korpus 
para pelatih yang telah memberikan banyak

ilmu, dan para penulis jurnal yang tulisannya menjadi objek kajian, serta teman-teman dan keluarga besar Pelatihan Penulisan Karya Tulis IImiah Jurnal Teknodik 2017. Tak lupa juga ucapan terima kasih kepada Lembaga Pengelola Dana Pendidikan (LPDP) yang telah mendukung penulis dari awal hingga akhir. 